\title{
Comparison of Farmers' Markets and District Markets in Terms of Marketing Efficiency: The Case of Seferihisar District in Izmir Province
}

\author{
Muhammed Çuhadar (Corresponding author) \\ Kahramanmaraş Sütçü İmam University, Faculty of Agriculture, Department of \\ Agricultural Economics, 46050 Kahramanmaraş, Turkey \\ Tel: 00905466784178 E-mail: muhammedcuhadar@gmail.com
}

Hakan Adanacioğlu

Ege University, Faculty of Agriculture, Department of Agricultural Economics, 35040

Izmir, Turkey

$00905322204840 \quad$ E-mail: hakan.adanacioglu@ege.edu.tr

\begin{abstract}
Naciye Oruç
Ege University, Faculty of Agriculture, Department of Agricultural Economics, 35040 Izmir, Turkey

00905419226291 E-mail: ncy.oruc@hotmail.com
\end{abstract}

Hümeyra Şahin

Ege University, Faculty of Agriculture, Department of Agricultural Economics, 35040 Izmir, Turkey

$00905419226291 \quad$ E-mail: humeyra-sahin61@hotmail.com

Received: July 10, $2019 \quad$ Accepted: August 12, $2019 \quad$ Published: August 19, 2019

doi:10.5296/jas.v7i3.15057

URL: https://doi.org/10.5296/jas.v7i3.15057 


\section{Abstract}

Marketing is a process that begins before the production of goods and continues even after the sale has been made. That is why it is essential to market effectively and accurately. Besides, many problems occur sourced from production and marketing. The most important one of these problems is that the marketing system is controlled by intermediaries. Excessive intermediaries lead to product losses and costs. While farmers sell the goods at low prices, the excess marketing channels cause product prices to increase until it reaches consumers. In this context, as determining the marketing efficiency of farmers, it is aimed to offer solutions to these problems. The research area of this study is the farmers' market in Seferihisar district of Izmir province in Turkey. It was interviewed face-to-face with 75 agricultural farmers in the research area. According to the obtained study results, in the farmers' market, the product with the highest marketing efficiency index (MEI) was fresh onion (40.6). In district markets, the product with the highest MEI was found as leek with 5.80. The study also showed that as farm size increased, farmers had a higher MEI.

Keywords: farmers' markets, direct marketing, marketing efficiency, agriculture

\section{Introduction}

Fresh fruits and vegetables have an essential place in our everyday life needs. These products are consumed by every segment of the society at all seasons and are also critical both economically and healthily (Çetin, 2009). According to the most recent data of the Food and Agriculture Organization of the United Nations (FAO) in 2016, 57 million hectares of fresh vegetables were harvested in the world. The total amount of fresh vegetables grown in the land is about 1.1 billion tons, and tomato is the most grown fresh vegetable product in the world with a production of about 177 million tons. By the year 2016, total fresh vegetable production has increased by $2.3 \%$ compared to 2015. According to the FAO data of 2016; with a production of 540 million tons, the People's Republic of China (PRC) is the country that produces the most significant amount of vegetables in the world. PRC has a $50.3 \%$ share of the world's fresh vegetable production. PRC's annual vegetable production is followed by India (119 million tons) and the United States (33 million tons) respectively. Turkey ranks fourth in the world rankings with a production of 24 million tons and $2.27 \%$ share of the global vegetable production. According to the FAO data of 2016; PRC is the country that produces the most significant amount of fruit in the world with a share of $25.9 \%$ and a production of around 38 million tons. PRC is followed by Brazil (19.5 million tons, 13.3\% share), India (12.04 million tons, $8.2 \%$ share), Mexico (8.1 million tons, 5.5\% share) and the US (7.5 million tons, $5.1 \%$ share). Turkey ranks ninth in the world ranking with about 4.3 million tons of fresh fruit production (2.9\%) (FAO, 2016). According to the Turkish Statistical Institute (TurkStat) data of 2018, a total of 52.31 million tons of fruit and vegetables produced in Turkey (22.28 million tons of fruit, 30.03 million tons of vegetable). When we take a look at the production composition of Turkey, it is observed that vegetables cultivated for their fruits such as tomato, cucumber, pepper, eggplant and watermelon have a share of $82.17 \%$ of the total vegetable production. Thus, with a production volume of 12.7 million tons, the tomato is the most grown vegetable and has a share of $41.3 \%$ of the total 
vegetable production in Turkey. Tomato is followed by watermelon and pepper (for processed, capia, bell, green and banana) in terms of production amount. Onion which is from the group of bulb and root vegetables is in third place with the production of 2.1 million tons. It is stated that in 2017, the global vegetable farming market was valued at approximately $\$ 1.9$ trillion. The share of Asia Pasific is $67.3 \%$ of the global market and China is the largest country with $\$ 1153.2$ billion of the global vegetable market (Anonymous, 2018). In addition to this, the fruit and nut farming market is estimated to reach nearly $\$ 1042.45$ billion by 2022 . (Anonymous, 2019). These figures show us that the marketing of these products is essential.

A farmers' market is one of the markets widely used in direct marketing. The farmers' market is defined as a common area where farmers sell fresh fruit and vegetables and other agricultural products directly to consumers at independent stands (Martinez et al., 2010). The farmers' markets in the US, have various names such as open-air markets, curb markets, commodity produce markets and producer-retailer markets (Burt et al., 2008).

In Turkey, the farmers' market was named as "villager market" by the public while it is defined as "producer market" officially. In this definition, the farmers' market is stated as "open or closed market places where farmers sell their products to retail consumers directly" (The Official Gazette, 2010; Adanacioğlu, 2014). In Turkey, it is possible to say that until now, the farmers' markets are not well developed. Farmers often try to market their products through district markets established in the district or provincial centres, but in these markets, it is often seen that people, who are known as "stallholder" who buy and sell products from wholesale markets, are on the action (Adanacioğlu, 2014).

Marketing channels vary according to the product, organisation level, competition and trade policies of the country. There are various marketing systems in fresh fruit and vegetable trade in the world (Yurdakul, 2018). Products are delivered to consumers either directly or through marketing channels that include various intermediaries. In this study, marketing systems are set according to the specified separation. In the direct marketing systems, the farmer himself/herself is on the market as a seller. In this system, farmers sell directly to the consumers with methods such as farmers' market, district market, organic product market, street/road/garden/field side sales, electronic commerce and open wholesale product sales centres (Albayrak, 2009). Agricultural marketing concept; starting with the quantity and quality of the product that the farmer will produce, including product preparation, standardisation, storage, transportation and finally the entire process up to the consumers (TZOB, 2003). Fresh fruits and vegetables have different processes in various stages and markets of marketing channels. These stages or markets in a traditional marketing system are seen as farmer, wholesaler and retailer (Yurdakul, 2002). In farmers' markets, the product is sold by the farmers; in other words, the farmers sell their own products. Wholesaler markets are the markets where the products bought by a collector from farmers and sold to other buyers such as processing plants and big wholesalers. The retail market is the sales place that provides consumers to reach the products that are bought from the wholesale markets, or other intermediaries, that is, it is the place where the products are bought by the end consumers (Akpinar et al., 2009). 
The concept of direct marketing in agriculture is described in different definitions in studies conducted in this field. The most common definition used in these studies is; "Direct sales to consumers", while in some studies specific sales places (restaurants, hospitals, schools, markets, and other retail outlets) were included as well as consumers. There are many direct marketing options available for farmers. The most common ones among these options are; pick your own, road-side stands and markets, farmers' markets, internet and mail order, direct sales to restaurants and institutions, community-supported agriculture and agro-tourism activities (Adanacıoğlu, 2014).

It is emphasised that marketing problems are essential as well as problems arising from the production in almost all of the case studies on fresh fruits and vegetables. Marketing problems can be divided into two parts:

1. Problems caused by physical processes such as classification, packaging, storage for marketing purposes.

2. Affecting producer income through the effects of the factors in the marketing chain on price.

It is observed that product losses are significant and the costs are high in agricultural products due to the surplus of transfer and irregularities in distribution until reaching consumer markets. It is even more apparent in fresh fruit and vegetable marketing. Brokers, traders, merchant brokers, shipper traders, producers, and cooperatives are the primary intermediaries in the producer area. The transportation of the products from the production zone to the consumption zone causes the problems of not making the fee according to the distance principle. There are no standard products on the domestic market because there is no procedure other than eye care classification in the garden. Price differences between production and consumption centres have reached considerable size due to the efficiency of firms and brokers in the fresh fruit and vegetable distribution channel on the market. While a significant portion of the money paid by the consumer remains on the marketing channel, a small part returns to the farmer (Pezikoğlu et al., 2004).

Turkey, although the fresh fruit and vegetable production has an essential place in the domestic and foreign markets, these products are not sufficiently effective in marketing. The fact that fresh vegetable and fruit are rapidly deteriorating products, marketing channels are long, and the fact that the intermediaries are large, cause to increase of product prices, while a small part of the price paid by the consumer passes to the farmers. Therefore, the fact that there are more intermediaries in agriculture and fruit marketing channels leads to an increase in marketing margins. Besides, the forms of marketing in which environmental and human health taken into consideration are also relevant today. Nevertheless, in marketing, informality has not been sufficiently prevented despite legal sanctions. Also, it is crucial for the farmers, intermediaries and consumers that fresh vegetable and fruit marketing channel is effective and sufficient (Kadanal1, 2013).

This study attempts to answer the basic question: Can vegetables and fruits be efficiently marketed in farmers' markets in comparison with the regional district's markets? Also, further suggestions were put forward on how to use strategies by growers, market managers, and 
policymakers in order to improve marketing efficiency in farmers' markets.

Many types of research in the field of food are superficially focused on the food sources sold in the store. Especially in urban societies, there is relatively little interest in food sources sold in non-storefront. The farmers' market, which the food is not sold in a store, is a kind of food source that may be important in urban societies. Farmers' markets, almost globally, have been recognised and supported as an existing structure to provide fresh fruit and vegetables to the regions with access difficulties (Lucan et al., 2015).

Some studies show that farmers' markets provide economic benefits to producers, consumers, and local communities (Sanderson et al., 2005; Otto and Varner, 2005; Henneberry et al., 2009; Day, 2012). Henneberry et al. (2009) pointed out that the contribution of farmers markets to the U.S. economy had become more significant due to the increased demand for fresh, locally produced products.

Based on the literature reviewed, many previous studies have attempted to investigate marketing performance assessments of agricultural products in market channels. On the other hand, there are relatively few studies that focus on determining marketing efficiency at farmers' markets or other forms of direct selling (Dastagiri et al., 2012; Mukherjee, 2013).

Dastagiri et al., (2012) studied the market costs, market margins, price spread, the producer's share of the consumer's rupee and the market efficiency of horticultural commodities under different supply chains. One of the significant findings was the fact that the highest marketing efficiency was found in the producer-to-consumer channel. Dastagiri et al. pointed out that government policies should promote direct marketing models for more efficient horticultural marketing.

Mukherjee (2013) examined the performance of the Rythu bazaars in the Greater Hyderabad city, capital of Andhra Pradesh. He pointed out that Rythu bazaars were one of the most successful implementations of the direct marketing models in India, formed in Andhra Pradesh in 1999. The author used Shepherd's and Acharya approach to measure the marketing efficiency of the Rythu bazaars and the local market. According to the study marketing efficiency was more in Rythu bazaars for tomato (6.31), okra (6.83), brinjal (5.41), and green chillies (7.90) at the overall level when compared to local market i.e., tomato (1.79), okra (2.41), brinjal (2.01), and green chillies (2.38). The study indicated that all the Rythu bazaars were much more efficient than the local market. The study further highlighted that it was because of two main reasons; first, farmers received a more net price for the products in Rythu bazaars than that of the local market; secondly, total marketing cost was quite high in the local market than the Rythu bazaars.

\section{Material and Methods}

The primary material of the study was the data obtained from face-to-face surveys with farmers in the farmers' market located in Seferihisar District, İzmir Province in 2016. The secondary data of the research was related to the previous research, report, review, dissertation, article, sources and data published by national and international research institutions such as TurkStat, and FAO. The farmers' market located in Seferihisar district of 
Izmir was taken into the scope of the research. The sample size was determined as using exact count method as 100 farmers (the number of registered farmers in the Seferihisar farmers' market registered by Izmir Metropolitan Municipality, Directorate of Wholesale Market). However, only 75 farmers were reached during the survey study. These 75 farmers in the farmers' market also worked in the district markets. Information such as sales price and the quantity related to the district market was also obtained from these farmers. All the data in the tables were obtained from the survey.

In this study, besides the marketing margins, the marketing efficiency of the farmers was calculated. In the broadest sense, marketing efficiency is defined as the ratio of market output (benefit) to marketing input (cost of resources). The increase in this rate indicates that there is a recovery on efficiency (Hussein et al., 2013). When marketing efficiency is calculated, Acharya's Modified Marketing Efficiency formula, one of the most widely used measures, was utilised;

$\mathrm{MME}=\mathrm{NPF} /(\mathrm{MC}+\mathrm{NMM}+\mathrm{ML})$ (Murthy et al., 2007).

MME : Modified marketing efficiency

NPF : Net price earned by farmers

MC : Total marketing expenditure by farmers and intermediaries (packaging, transportation, labour, and commission fees)

NMM : Total net marketing margin achieved by the intermediaries

ML : The value of physical losses until the product reaches to market

However, the MME = NPF / $(\mathrm{MC}+\mathrm{NMM})$ formula, which is widely used in the literature, was utilised because the value of physical product losses cannot be determined on the step of intermediaries. The higher the efficiency index found in the calculation, the higher the marketing efficiency of farmers. An increase in this ratio would represent improved efficiency and vice-versa.

Also, in the study, it was benefited from a formula showing the share of net prices in consumer prices, which was used as one of the indicators of farmer's marketing performance.

$\mathrm{PSCP}=(\mathrm{NMPP} / \mathrm{CP}) \times 100$ (Imtiyaz and Soni, 2013).

PSCP : Farmer's share in consumer prices

NMPP : Net price earned by farmers

$\mathrm{CP}$ : Consumer price

In the study, Mann Whitney U test was also used in order to determine if there is a significant difference between farmer's market and district market prices and marketing efficiency indexes. The Man Whitney $U$ test is a nonparametric test that can be used as an alternative to the t-test. This test was developed by Man, Whitney and Wilcoxon. (Miran, 2018). This technique is used to test for differences between two independent groups measured continuously. As in the t-test, instead of comparing the means of the two groups, the Man Whitney U test compares the median of the groups (Kalayc1, 2014). 


\section{Results}

\subsection{Socio-Economic Characteristics of the Farmers}

The average age of the farmers is 46.23 . The number of households is 3.84 persons, the average household income is $€ 1970$ (Turkish Liras), and the average non-agricultural income is $€ 284$ (see below Table 1). While the average time working as a farmer is 24 years, the total number of employees on the farm is 3.52 persons, and 2.23 of them are provided within the family.

$27 \%$ of the respondents participating in the survey study are females, and $91 \%$ of the farmers are married. Only 5\% of the farmers are graduated from university, and $17 \%$ of them have no social security. Most of the farmers do not have a membership to any cooperative (64\%), and $55 \%$ of them provide labour force within the family (Table 1).

Table 1. Socio-economic characteristics of the farmers

\begin{tabular}{|c|c|c|}
\hline \multicolumn{2}{|c|}{ Socio-economic characteristics } & Average \\
\hline \multicolumn{2}{|c|}{ Age } & 46.23 \\
\hline \multicolumn{2}{|l|}{ Number of households } & 3.84 \\
\hline \multicolumn{2}{|c|}{ Average household income per month (も)* } & 1970.00 \\
\hline \multicolumn{2}{|c|}{ Non-agricultural average income per month (も)* } & 284.00 \\
\hline \multicolumn{2}{|c|}{ The time working as a farmer (year) } & 24.00 \\
\hline \multicolumn{2}{|c|}{ Total number of employees on the farm } & 3.52 \\
\hline \multicolumn{2}{|c|}{ Number of family employees } & 2.23 \\
\hline & & Percentage $(\%)$ \\
\hline \multirow{2}{*}{ Gender } & Female & 27 \\
\hline & Male & 73 \\
\hline \multirow{2}{*}{ Marital Status } & Married & 91 \\
\hline & Single & 9 \\
\hline \multirow{5}{*}{ Educational Status } & Illiterate & 5 \\
\hline & Primary School & 60 \\
\hline & Secondary School & 15 \\
\hline & High School & 15 \\
\hline & University & 5 \\
\hline \multirow{2}{*}{ Social Security } & Yes & 83 \\
\hline & No & 17 \\
\hline \multirow{2}{*}{$\begin{array}{l}\text { Membership to any } \\
\text { cooperative }\end{array}$} & Yes & 36 \\
\hline & No & 64 \\
\hline \multirow{3}{*}{ Labour force } & Within the family & 55 \\
\hline & Non-family & 37 \\
\hline & Both & 8 \\
\hline
\end{tabular}

*The average exchange rates between Turkish Liras ( $€$ ) and the US dollars (\$) for February 2016 is $\$ 1=€ 2.95$ (CBRT, 2016).

\subsection{The Information About the Farmers' Markets}

Farmers participating in the survey study earn an average monthly income of $€ 978.37$ from the farmers' market. It has been determined that farmers have been operating in the farmers' 
market for about five years on average. The average distance between the farmers' market and the farm is about $20 \mathrm{~km}$ and the market place monthly rental cost is about $€ 60$ on average. $71 \%$ of the farmers indicate that operating in the farmers' market has increased their income, and $90 \%$ of them take their products to the farmers' market by private vehicle (Table 2).

Table 2. The information about the farmers' market

\begin{tabular}{|c|c|c|}
\hline & & Average \\
\hline \multicolumn{2}{|l|}{ The time working in farmers' market (year) } & 4.92 \\
\hline \multicolumn{2}{|c|}{ Working time in the farmers' market during the day (hour) } & 10.53 \\
\hline \multicolumn{2}{|c|}{ The distance between the farmers' market and farm $(\mathrm{km})$} & 19.51 \\
\hline \multicolumn{2}{|c|}{ Farmers' market place monthly rental cost $(€)^{*}$} & 60.44 \\
\hline \multirow{2}{*}{\multicolumn{2}{|c|}{ Average income earned in farmers' market per month (も)* }} & 978.67 \\
\hline & & Percentage \\
\hline \multirow{3}{*}{$\begin{array}{l}\text { The impact of selling in farmers' market } \\
\text { on income }\end{array}$} & Increased & 71 \\
\hline & No change & 24 \\
\hline & Decreased & 5 \\
\hline \multirow{3}{*}{ How to take products to market } & By private vehicle & 90 \\
\hline & By rental vehicle & 7 \\
\hline & Others & 3 \\
\hline
\end{tabular}

*The average exchange rates between Turkish Lira (も) and the US dollar (\$) for February 2016 is $\$ 1$ = 2.95 (CBRT, 2016).

\subsection{The Information About Land Use}

$67 \%$ of the farmers are processing their property land, and $24 \%$ of them are processing rental land. The average land size of farmers interviewed is 20.85 decares, and farmers are processing 18.52 decares of it. The farmers allocated 6.69 decares land for fruit and 9.83 decare land for vegetable production (Table 3 ).

Table 3. The information about land use

\begin{tabular}{l|c}
\hline Land use & Percentage \\
\hline Property land & 67 \\
Rental land & 24 \\
Sharecropping & 8 \\
Others & 1 \\
\hline & Average (decare*) \\
\hline Total land size & 20.85 \\
Total processed land & 18.52 \\
Land allocated for fruit production & 6.69 \\
Land allocated for vegetable production & 9.83 \\
\hline
\end{tabular}

Source: Survey study

$* 1$ decare $=0.1$ hectares 


\subsection{Farms by Land Size}

While $24 \%$ of the farms involved in the survey have a size above 29 decare, $40 \%$ have a size of less than 10 decare. $36 \%$ of the farms have a size of 10-29 decares (Table 4).

Table 4. Farms by land size

\begin{tabular}{l|c|c}
\hline $\begin{array}{l}\text { Farms size class } \\
(\text { decare*) }\end{array}$ & Count & Percentage \\
\hline$<10$ & 30 & 40 \\
\hline $10-29$ & 27 & 36 \\
\hline$>29$ & 18 & 24 \\
\hline Total & 75 & 100 \\
\hline
\end{tabular}

Source: Survey study

$* 1$ decare $=0.1$ hectares

\subsection{Fruit Production in the Winter Season}

The interviewed farmers allocated the most significant area for olive in winter with 29.25 decares. The production amount of olive is $25000 \mathrm{~kg}$, and the average sale price is $€ 2.13$. Olive is followed by lemon and mandarin in terms of allocated area for production (Table 5).

Table 5. The fruits grown in winter

\begin{tabular}{l|c|c|c}
\hline Products & Production area (decare*) & Production amount $(\mathrm{kg})$ & Sale price $(€ / \mathrm{kg})$ \\
\hline Olive & 29.25 & 25000.00 & 2.13 \\
\hline Lemon & 3.15 & 10500.00 & 4.00 \\
\hline Mandarin & 5.80 & 10247.50 & 1.17 \\
\hline Orange & 1.80 & 1841.67 & 1.33 \\
\hline Pomegranate & 1.30 & 1704.17 & 2.83 \\
\hline Grapefruit & 0.25 & 300.00 & 2.00 \\
\hline
\end{tabular}

Source: Survey study $* 1$ decare $=0.1$ hectares

\subsection{Vegetable Production in the Winter Season}

The interviewed farmers allocated the most significant area for potatoes in winter with 7.5 decares. The production amount of potatoes is $27500 \mathrm{~kg}$, and the average sale price is $€ 1.75$. Potatoes are followed by globe artichoke and creeping thistle in terms of allocated area for production (Table 6). 


\section{Macrothink}

Journal of Agricultural Studies

ISSN 2166-0379

2019, Vol. 7, No. 3

Table 6. The vegetables grown in winter

\begin{tabular}{|c|c|c|c|}
\hline Products & Production area (decare*) & Production amount $(\mathrm{kg})$ & $\begin{array}{c}\text { Sale price } \\
\text { (も/kg) }\end{array}$ \\
\hline Potatoes & 7.50 & 27500.00 & 1.75 \\
\hline Globe artichoke & 4.75 & 7766.67 & 3.25 \\
\hline Creeping thistle & 3.50 & 1866.67 & 8.33 \\
\hline Cabbage $^{1}$ & 3.31 & 3548.02 & 2.20 \\
\hline Spinach & 2.70 & 1877.21 & 2.64 \\
\hline Cauliflower ${ }^{1}$ & 2.32 & 2022.63 & 2.28 \\
\hline Onion & 2.00 & 4000.00 & 3.00 \\
\hline Garlic & 1.51 & 1020.00 & 13.50 \\
\hline Lettuce $^{1}$ & 1.24 & 8435.42 & 1.34 \\
\hline Broccoli & 1.05 & 549.78 & 2.68 \\
\hline Winter squash & 1.03 & 2002.50 & 1.75 \\
\hline Carrot & 1.00 & 2000.00 & 2.00 \\
\hline Leek & 0.93 & 1936.38 & 2.43 \\
\hline Celery & 0.90 & 1825.96 & 2.58 \\
\hline Beet & 0.88 & 533.33 & 2.00 \\
\hline $\mathrm{Dill}^{2}$ & 0.63 & 3100.00 & 0.38 \\
\hline Parsley $^{2}$ & 0.56 & 3605.56 & 0.29 \\
\hline Garden rocket ${ }^{2}$ & 0.51 & 10025.00 & 0.14 \\
\hline Fennel & 0.50 & 3000.00 & 4.00 \\
\hline Fresh Onion $^{2}$ & 0.31 & 280.96 & 1.61 \\
\hline Chard $^{2}$ & 0.28 & 188.75 & 1.63 \\
\hline Purple cabbage $^{1}$ & 0.25 & 150.00 & 1.50 \\
\hline Turnip & 0.24 & 404.72 & 1.92 \\
\hline
\end{tabular}

Source: Survey study $* 1$ decare $=0.1$ hectare $\quad{ }^{1}$ Count $\quad{ }^{2}$ Bunch

\subsection{Fruit Production in the Summer Season}

The interviewed farmers allocated the most significant area for grape in summer with 9.17 decares. The production amount of the grape is $5375 \mathrm{~kg}$, and the average sale price is $€ 3.46$. The grape is followed by cherry and watermelon in terms of allocated area for production (Table 7). 
Table 7. The fruits grown in summer

\begin{tabular}{l|c|c|c}
\hline Products & Production area (decare*) & Production amount $(\mathrm{kg})$ & $\begin{array}{c}\text { Sale price } \\
(\text { も/kg })\end{array}$ \\
\hline Grape & 9.17 & 5375.00 & 3.46 \\
\hline Cherry & 7.67 & 8375.00 & 4.38 \\
\hline Watermelon & 5.23 & 13508.33 & 1.26 \\
\hline Apple & 5.00 & 3000.00 & 1.00 \\
\hline Melon & 3.88 & 6644.44 & 6.30 \\
\hline Strawberry & 2.75 & 3000.00 & 5.00 \\
\hline Plum & 2.16 & 876.67 & 2.17 \\
\hline Peach & 1.13 & 610.00 & 2.25 \\
\hline Pear & 1.04 & 1287.50 & 3.13 \\
\hline Fig & 0.98 & 677.78 & 3.78 \\
\hline Quince & 0.75 & 510.00 & 3.00 \\
\hline Apricot & 0.28 & 250.00 & 3.00 \\
\hline Mulberry & 0.25 & 500.00 & 5.00 \\
\hline Jujube & 0.01 & 50.00 & 10.00 \\
\hline Source: Survey & $* 14$ & & \\
\hline
\end{tabular}

Source: Survey study

$* 1$ decare $=0.1$ hectares

\subsection{Vegetable Production in the Summer Season}

The interviewed farmers allocated the most significant area for tomatoes in summer with 7.14 decares. The production amount of tomatoes is $5318.06 \mathrm{~kg}$, and the average sale price is €1.51. Tomatoes are followed by zucchini and corn in terms of allocated area for production (Table 8). 


\section{Macrothink}

Table 8 . The vegetables grown in summer

\begin{tabular}{l|c|c|c}
\hline Products & Production area (decare*) & Production amount $(\mathrm{kg})$ & $\begin{array}{c}\text { Sale price } \\
(も / \mathrm{kg})\end{array}$ \\
\hline Tomatoes & 7.14 & 5318.06 & 1.51 \\
\hline Zucchini & 2.49 & 3806.67 & 1.85 \\
\hline Maize & 2.00 & 2000.00 & 1.00 \\
\hline Okra & 1.69 & 481.25 & 7.63 \\
\hline Green cowpea & 1.48 & 569.58 & 3.34 \\
\hline Eggplant & 1.21 & 2302.26 & 1.55 \\
\hline Cucumber & 1.20 & 8495.00 & 1.36 \\
\hline Green pepper & 0.96 & 1163.85 & 1.73 \\
\hline Green bean & 0.66 & 475.00 & 2.11 \\
\hline Long green pepper & 0.50 & 800.00 & 2.00 \\
\hline Cranberry beans & 0.50 & 300.00 & 2.50 \\
\hline Source: Survey study & & & \\
\hline
\end{tabular}

Source: Survey study $* 1$ decare $=0.1$ hectares

\subsection{Marketing Efficiency}

Among the products in the farmers' market, green cowpea has the highest transportation cost with $€ 0.32$ per $\mathrm{kg}$. This order is followed by creeping thistle (も0.16), pomegranate ( $€ 0.12$ ) and zucchini (£0.11). Among these products, lettuce is the product which has minimum transportation costs with $€ 0.002$ (Table 9).

Table 9. Transportation cost of the products

\begin{tabular}{l|l|l|l|l|c}
\hline Products & も/kg & Products & も/kg & Products & も/kg \\
\hline Green cowpea & 0.32 & Cauliflower & 0.09 & Celery & 0.02 \\
\hline Creeping thistle & 0.16 & Winter squash & 0.08 & Tomatoes & 0.01 \\
\hline Pomegranate & 0.12 & Leek & 0.05 & Cabbage $^{1}$ & 0.01 \\
\hline Zucchini & 0.11 & Green pepper & 0.05 & Spinach $^{1}$ & 0.01 \\
\hline Eggplant & 0.11 & Mandarin & 0.03 & Lettuce $^{1}$ & 0.002 \\
\hline Beet & 0.10 & Cucumber & 0.02 & & \\
\hline
\end{tabular}

Source: Survey study $\quad{ }^{1}$ Count

Among the products in the farmers' market, okra has the highest packing cost of $€ 0.38$ per kg. This order is followed by cabbage ( $€ 0.26)$, green cowpea (€0.19) and grape (Ł0.17). Among these products, garden rocket is the product which has minimum packing costs at $€ 0.001$ (Table 10). 


\section{Mll Macrothink}

Table 10. Packing cost of the products

\begin{tabular}{|c|c|c|c|c|c|}
\hline Products & も/kg & Products & も/kg & Products & も/kg \\
\hline Okra & 0.38 & Pomegranate & 0.08 & Strawberry & 0.02 \\
\hline Cabbage $^{1}$ & 0.26 & Chard $^{2}$ & 0.07 & Onion & 0.02 \\
\hline Green cowpea & 0.19 & Cucumber & 0.06 & Green pepper & 0.02 \\
\hline Grape & 0.17 & Fig & 0.06 & Celery & 0.02 \\
\hline Pear & 0.17 & Beet & 0.06 & Dill $^{2}$ & 0.02 \\
\hline Peach & 0.15 & Broccoli & 0.05 & Potatoes & 0.01 \\
\hline Mandarin & 0.12 & Watermelon & 0.03 & Leek & 0.01 \\
\hline Creeping thistle & 0.11 & Tomatoes & 0.03 & Spinach & 0.01 \\
\hline Zucchini & 0.11 & Fresh onion $^{2}$ & 0.03 & Plum & 0.01 \\
\hline Turnip & 0.10 & Lettuce $^{1}$ & 0.02 & Orange & 0.01 \\
\hline Eggplant & 0.08 & Cherry & 0.02 & Garlic & 0.01 \\
\hline Winter squash & 0.08 & Lemon & 0.02 & Parsley $^{2}$ & 0.006 \\
\hline Cauliflower $^{1}$ & 0.08 & Globe artichoke & 0.02 & Garden rocket $^{2}$ & 0.001 \\
\hline
\end{tabular}

Among the products in the farmers' market, strawberry and garden rocket have the highest wastage rate with $20 \%$. This order is followed by zucchini $(18.75 \%)$, tomatoes $(11.62 \%)$ and cucumber $(11 \%)$. Among these products, garlic is the product which has minimum wastage rate with $0.50 \%$ (Table 11 ).

Table 11. Wastage rate of the products

\begin{tabular}{l|c|l|c|l|c}
\hline Products & \multicolumn{1}{|c|}{$\%$} & Products & $\%$ & Products & $\%$ \\
\hline Strawberry & 20.00 & Cherry & 9.17 & Pear & 5.00 \\
\hline Garden rocket & 20.00 & Grape & 8.75 & Peach & 5.00 \\
\hline Winter squash & 18.75 & Potatoes & 8.50 & Onion & 5.00 \\
\hline Tomatoes & 11.62 & Eggplant & 8.48 & Fig & 5.00 \\
\hline Cucumber & 11.00 & Green pepper & 7.94 & Plum & 5.00 \\
\hline Globe artichoke & 10.83 & Spinach & 7.39 & Pomegranate & 5.00 \\
\hline Mandarin & 10.50 & Leek & 6.89 & Parsley & 5.00 \\
\hline Lemon & 10.00 & Cauliflower & 6.88 & Dill & 5.00 \\
\hline Winter squash & 10.00 & Celery & 6.35 & Okra & 3.00 \\
\hline Orange & 10.00 & Beet & 6.25 & Broccoli & 1.75 \\
\hline Lettuce & 9.46 & Cabbage & 6.04 & Turnip & 1.67 \\
\hline Watermelon & 9.33 & Green cowpea & 5.08 & Garlic & 0.50 \\
\hline
\end{tabular}

Source: Survey study

On the table below, the net price is calculated as subtracting load and carry, packing and wastage costs from the gross price of the products which all cost data is available (Table 12). 
Table 12. Net price in the farmers' market

\begin{tabular}{|c|c|c|c|c|c|}
\hline Products & $\begin{array}{c}\text { Gross price } \\
\text { も/kg } \\
(1)\end{array}$ & $\begin{array}{c}\text { Transportation } \\
\text { cost } € / \mathrm{kg} \\
\text { (a) }\end{array}$ & $\begin{array}{l}\text { Packing cost } \\
\text { も/kg } \\
\text { (b) }\end{array}$ & $\begin{array}{c}\text { Wastage } \\
\text { cost } € / \mathrm{kg} \\
\text { (c) }\end{array}$ & $\begin{array}{c}\text { Net Price } \\
\text { も/kg } \\
\{1-(a+b+c)\}\end{array}$ \\
\hline Celery & 2.53 & 0.02 & 0.02 & 0.16 & 2.33 \\
\hline Spinach & 2.46 & 0.01 & 0.05 & 0.18 & 2.22 \\
\hline Leek & 2.48 & 0.05 & 0.03 & 0.17 & 2.22 \\
\hline Cauliflower ${ }^{1}$ & 2.11 & 0.09 & 0.08 & 0.16 & 1.77 \\
\hline Fresh onion $^{2}$ & 1.65 & 0.00 & 0.04 & 0.00 & 1.61 \\
\hline Lettuce $^{1}$ & 1.49 & 0.00 & 0.01 & 0.14 & 1.34 \\
\hline Orange & 1.25 & 0.00 & 0.01 & 0.13 & 1.11 \\
\hline Mandarin & 1.36 & 0.03 & 0.12 & 0.14 & 1.06 \\
\hline
\end{tabular}

Source: Survey study

${ }^{1}$ Count $\quad{ }^{2}$ Bunch

When the marketing efficiency index (MEI) which is an essential indicator of the marketing performance of the farmers, was investigated by the products, the highest MEI in the farmers' market was found as 40.6 (fresh onion). The product with the lowest marketing efficiency is mandarin with 3.53 (Table 13).

Table 13. Marketing efficiency index in the farmers' market

\begin{tabular}{|c|c|c|c|c|c|}
\hline Products & $\begin{array}{c}\text { Net Price } \\
\text { も/kg } \\
(1)\end{array}$ & $\begin{array}{c}\text { Total } \\
\text { Marketing } \\
\text { cost } € / \mathrm{kg} \\
\text { (2) }\end{array}$ & $\begin{array}{c}\text { Wastage } \\
\text { cost } ⿻ / \mathrm{kg} \\
(3)\end{array}$ & $\begin{array}{c}\text { Net } \\
\text { Marketing } \\
\text { Margin } \\
\text { (4) }\end{array}$ & $\begin{array}{c}\text { Marketing } \\
\text { Efficiency } \\
\text { Index } \\
\{1 /(2+3+4)\}\end{array}$ \\
\hline Fresh onion $^{2}$ & 1.61 & 0.04 & 0.00 & 0.00 & 40.60 \\
\hline Celery & 2.33 & 0.04 & 0.16 & 0.00 & 11.60 \\
\hline Spinach & 2.22 & 0.06 & 0.18 & 0.00 & 9.23 \\
\hline Leek & 2.22 & 0.08 & 0.17 & 0.00 & 8.85 \\
\hline Lettuce $^{1}$ & 1.34 & 0.01 & 0.14 & 0.00 & 8.76 \\
\hline Orange & 1.11 & 0.01 & 0.13 & 0.00 & 7.95 \\
\hline Cauliflower ${ }^{1}$ & 1.77 & 0.18 & 0.16 & 0.00 & 5.22 \\
\hline Mandarin & 1.06 & 0.16 & 0.14 & 0.00 & 3.53 \\
\hline
\end{tabular}

As the farm size increases, it is seen that the MEI also increases. It is due to the farmers who have larger lands, bring in more products and reduce the share of some of the costs in the products. The product with the highest MEI was found as fresh onion for all farm sizes. It is because there is no wastage cost, and the cost of marketing is very low in fresh onion (Table 14). 
Table 14. Marketing efficiency index by farm size

\begin{tabular}{l|c|c|c}
\hline \multirow{2}{*}{ Products } & \multicolumn{3}{|c}{ Farm Size } \\
\cline { 2 - 4 } & $<10$ decare & $10-29$ decare & $>29$ decare \\
\hline Fresh onion & 46.66 & 26.87 & 56.88 \\
\hline Spinach & 5.20 & 6.81 & 16.39 \\
\hline Lettuce & 9.57 & 4.98 & 10.62 \\
\hline Mandarin & 7.60 & 3.18 & 4.35 \\
\hline Cauliflower & 5.61 & 6.87 & 12.07 \\
\hline Celery & 4.50 & 14.85 & 7.78 \\
\hline Orange & - & 7.7 & 8.12 \\
\hline Leek & 2.83 & 9.10 & - \\
\hline
\end{tabular}

Source: Survey study - -lack of data

The net price is calculated by subtracting transportation, packing and wastage costs from the gross prices of the products sold in the district market, which is one of the indirect marketing channels (Table 15).

Table 15. Net price in the district market

\begin{tabular}{l|c|c|c|c|c}
\hline Products & $\begin{array}{c}\text { Gross price } \\
\text { / } / \mathrm{kg} \\
(1)\end{array}$ & $\begin{array}{c}\text { Transportation } \\
\text { cost } / \mathrm{kg} \\
(\mathrm{a})\end{array}$ & $\begin{array}{c}\text { Packing cost } \\
\text { /kg } \\
(\mathrm{b})\end{array}$ & $\begin{array}{c}\text { Wastage cost } \\
\text { /kg } \\
(\mathrm{c})\end{array}$ & $\begin{array}{c}\text { Net Price } \\
\text { / } / \mathrm{kg} \\
\{1-(\mathrm{a}+\mathrm{b}+\mathrm{c})\}\end{array}$ \\
\hline Spinach & 2.67 & 0.00 & 0.01 & 0.20 & 2.45 \\
\hline Celery & 2.53 & 0.02 & 0.02 & 0.16 & 2.33 \\
\hline Leek & 2.31 & 0.01 & 0.01 & 0.16 & 2.14 \\
\hline Fresh onion $^{2}$ & 2.13 & 0.00 & 0.03 & 0.00 & 2.09 \\
\hline Cauliflower $^{1}$ & 2.22 & 0.07 & 0.06 & 0.17 & 1.91 \\
\hline Lettuce $^{1}$ & 1.57 & 0.00 & 0.02 & 0.15 & 1.40 \\
\hline Mandarin & 1.42 & 0.01 & 0.05 & 0.15 & 1.21 \\
\hline Orange & 1.33 & 0.00 & 0.01 & 0.13 & 1.19 \\
\hline
\end{tabular}

Source: Survey study $\quad{ }^{1}$ Count $\quad{ }^{2}$ Bunch

The product with the highest MEI in the district markets is leek with 5.80. At the same time, the leek is the product which farmers' share in consumer price is the highest. So, the higher the share of the farmer in the consumer price, the higher the MEI. The product with the lowest MEI is cauliflower with 0.60 . The increase in the number of intermediaries between the farmers and the consumers causes the MEI to decrease (Table 16). 
Table 16. Marketing efficiency index in the district market

\begin{tabular}{|c|c|c|c|c|c|c|}
\hline Products & $\begin{array}{c}\text { Net Price } \\
\text { も/kg } \\
(1)\end{array}$ & $\begin{array}{c}\text { Total } \\
\text { Marketing } \\
\text { cost } / \mathrm{kg} \\
(2)\end{array}$ & $\begin{array}{c}\text { Wastage } \\
\text { cost } € / \mathrm{kg} \\
\text { (3) }\end{array}$ & $\begin{array}{c}\text { Net } \\
\text { Marketing } \\
\text { Margin } \\
(4)\end{array}$ & $\begin{array}{c}\text { Marketing } \\
\text { Efficiency } \\
\text { Index } \\
\{1 /(2+3+4)\}\end{array}$ & $\begin{array}{c}\text { Farmers' share } \\
\text { in consumer } \\
\text { price } \% \\
\left\{(1 / 2)^{*} 100\right\}\end{array}$ \\
\hline Leek & 2.14 & 2.49 & 0.35 & 0.02 & 5.80 & 85.84 \\
\hline Spinach & 2.45 & 2.89 & 0.44 & 0.02 & 5.37 & 84.83 \\
\hline Celery & 2.33 & 2.99 & 0.66 & 0.04 & 3.31 & 77.81 \\
\hline Lettuce $^{1}$ & 1.40 & 1.99 & 0.59 & 0.02 & 2.29 & 70.39 \\
\hline Fresh onion $^{2}$ & 2.09 & 3.00 & 0.91 & 0.03 & 2.24 & 69.83 \\
\hline Orange & 1.19 & 2.79 & 1.60 & 0.01 & 0.74 & 42.77 \\
\hline Mandarin & 1.21 & 2.99 & 1.78 & 0.06 & 0.66 & 40.38 \\
\hline Cauliflower $^{1}$ & 1.91 & 3.29 & 3.08 & 0.13 & 0.60 & 58.11 \\
\hline
\end{tabular}

\subsection{Analysing Price Differences Between Farmers'Market and District Market}

It was analysed if there was a difference between the prices of the farmers' market and the district market by using the Mann Whitney $U$ test. As a result of the analysis, no significant difference was found between the prices of the products sold in these two markets (Table 17).

Table 17. Analysing the price difference of the products

\begin{tabular}{|c|c|c|c|c|}
\hline Products & \multicolumn{2}{|c|}{ Mean Rank } & $\mathrm{Z}$ & Sig \\
\hline \multirow{2}{*}{ Celery } & Farmers' market & 18.61 & \multirow{2}{*}{-0.086} & \multirow{2}{*}{$0.932 \mathrm{NS}$} \\
\hline & District market & 18.31 & & \\
\hline \multirow{2}{*}{ Cauliflower } & Farmers' market & 20.77 & \multirow{2}{*}{-0.543} & \multirow{2}{*}{$0.587 \mathrm{NS}$} \\
\hline & District market & 18.77 & & \\
\hline \multirow{2}{*}{ Cabbage } & Farmers' market & 20.90 & \multirow{2}{*}{-0.414} & \multirow{2}{*}{$0.679 \mathrm{NS}$} \\
\hline & District market & 22.38 & & \\
\hline \multirow{2}{*}{ Spinach } & Farmers' market & 19.04 & \multirow{2}{*}{-0.524} & \multirow{2}{*}{$0.600 \mathrm{NS}$} \\
\hline & District market & 17.10 & & \\
\hline \multirow{2}{*}{ Lettuce } & Farmers' market & 16.14 & \multirow{2}{*}{-0.345} & \multirow{2}{*}{$0.730 \mathrm{NS}$} \\
\hline & District market & 17.30 & & \\
\hline \multirow{2}{*}{ Leek } & Farmers' market & 15.45 & \multirow{2}{*}{-0.451} & \multirow{2}{*}{$0.652 \mathrm{NS}$} \\
\hline & District market & 14.00 & & \\
\hline
\end{tabular}

**Significant at 5\% level ***Significant at $1 \%$ level NS: Non Significance 
3.10 Analysing Marketing Efficiency Index Differences Between Farmers' Market and District Market

It was analysed if there was a difference between the farmers' market and the district market efficiency index by using the Mann Whitney $U$ test. As a result of the analysis, significant differences were found between farmers' and district market efficiency indexes of the products except for leek and cabbage. It is seen that the MEI of the products sold in the farmers' market are quite high compared to the district market (Table 18). This finding is generally consistent with findings from previous studies (Dastagiri et al., 2012; Mukherjee, 2013).

Table 18. Analysing marketing efficiency index difference of the products

\begin{tabular}{|c|c|c|c|c|}
\hline Products & \multicolumn{2}{|c|}{ Mean Rank } & $\mathrm{Z}$ & Sig \\
\hline \multirow{2}{*}{ Celery } & Farmers' market & 20.22 & \multirow{2}{*}{-2.546} & \multirow{2}{*}{$0.011 * *$} \\
\hline & District market & 11.71 & & \\
\hline \multirow{2}{*}{ Cauliflower } & Farmers' market & 22.88 & \multirow{2}{*}{-3.602} & \multirow{2}{*}{$0.000 * * *$} \\
\hline & District market & 10.75 & & \\
\hline \multirow{2}{*}{ Cabbage } & Farmers' market & 16.56 & \multirow{2}{*}{-1.533} & \multirow{2}{*}{$0.125 \mathrm{NS}$} \\
\hline & District market & 11.75 & & \\
\hline \multirow{2}{*}{ Spinach } & Farmers' market & 20.78 & \multirow{2}{*}{-3.408} & \multirow{2}{*}{$0.001 * * *$} \\
\hline & District market & 08.30 & & \\
\hline \multirow{2}{*}{ Lettuce } & Farmers' market & 20.57 & \multirow{2}{*}{-4.057} & \multirow{2}{*}{$0.000 * * *$} \\
\hline & District market & 06.40 & & \\
\hline \multirow{2}{*}{ Leek } & Farmers' market & 07.56 & \multirow{2}{*}{-1.548} & \multirow{2}{*}{$0.122 \mathrm{NS}$} \\
\hline & District market & 11.44 & & \\
\hline
\end{tabular}

**Significant at $5 \%$ level

\section{Discussion}

The farmers' markets in Turkey is yet undeveloped, and the number of them is quite low. It is because the legal regulations are new, and the sales are not at the desired levels yet. For farmers to sell their products directly to the consumers, which is a characteristic of the farmers' markets, helps to build trust between farmers and consumers by providing consumers with more information about the product.

Promotional activities towards farmers' markets are insufficient in Turkey. Many farmers do not yet know the existence of these markets. In order to attract consumers also to these markets, it is necessary to raise awareness about the farmers' market. The role of municipalities in the development of farmers' markets is rather high, so municipalities should implement some strategies that will attract consumers to these markets with their supporting efforts. In this context, farmers' markets should be reorganised taking these into account. 
The situations in which farmers in farmers' market apply consumer-friendly production methods are uncertain. In order for farmers' markets to be different from other markets, it is necessary to make the products healthy and consumer-friendly to be preferred by consumers. One of the most widespread problems today is the chemical input problem. The farmers use chemical inputs unconsciously. Consumers have become more conscious about this subject in recent years and do not prefer products produced in this way. Consumers have tended towards organic products instead of these products. For this reason, natural and healthy products should be offered to the consumers in farmers' markets without using chemical inputs.

\section{Conclusion}

As a conclusion, the farmers' market is quite close to the farms and this facilitates the products to arrive at the market and reduces transportation costs. In this respect, the farmers' market offers advantages for farmers. Inadequate storage in the farmers' market causes farmers to sell their remaining products to consumers at low prices in the evening hours, and it negatively affects farmers. In terms of price, there is no statistically significant price difference when we compare the prices of the products in farmers' and district markets. If we consider abroad, the prices of the products in farmers' markets are higher than district markets. It shows that the farmers' markets abroad are working more effectively than the ones in Turkey. In order to improve this situation and to increase marketing efficiency, the farmers' markets abroad can be modelled in Turkey.

Marketplace rental has become a significant problem for farmers. The farmers are disturbed by the market place rentals, and they are voicing it. It negatively affects small-scale farms, in particular. Small-scale farmers who earn very little profit, give a portion of their income as marketplace rents, and therefore, the income they earn is decreasing. Large-scale farm owners, who have more space to rent in the market, are selling at the foremost part of the market and in large areas while small-scale farm owners are selling in smaller areas and intermediate parts. For this reason, while large-scale farmers work more efficiently in the market, small-scale farmers cannot operate effectively. In this way, the market place rental, which is a problem for small-scale farmers, should be taken to a more reasonable level.

In the farmers' market, the farmers can only sell the products which are located in their territory, and it causes the product variety in the market to be small. It leads consumers to district markets. This problem is reducing the demand for the farmers' market. One of the proposals to solve this problem is to ensure that farmers producing different products from nearby regions come to farmers' markets and sell them. In this way, consumers should be offered more product diversity to increase demand and prefer farmers' markets. The fact that there are many district markets in the region and the presence of other retail outlets affects consumer demand differently. The small number of product varieties in farmers' markets has led consumers to be less interested in these markets. For this reason, it is essential that farmers' markets should be controlled under the leadership of an organisation.

There are many fundamental problems in the farmers' markets in Turkey. The most important one of these is the lack of adequate and effective audits by municipalities. Audits should be 
increased by municipalities in order to provide the development and continuance of the farmers' markets in a healthier way.

Another one of the most important problems is that the non-farmers sell in the farmers' market. They sell products on the farmers' market by buying them from a wholesale market hall and other intermediaries. In the farmers' market, everyone is selling their products without considering they are farmer or not. When we take a look at the examples of the farmers' markets abroad, the selection of farmers is made specially, and non-farmers cannot sell in these markets. In this case, the selection of farmers in the farmers' market should be made specially, and non-farmers should not be taken into the farmers' market. The farmers in Turkey also wants implementations of this system in this way. While selecting the farmers, a commission should be established not only by municipalities but also by universities and non-governmental organisations. If these measures are not taken, these markets will lose the ability to become a Farmers' market.

\section{References}

Adanacıoğlu, H. (2014). Tarımsal Ürünlerde Doğrudan Pazarlama Kavramı ve Pazarlama Etkinliği Açısından Dolaylı Pazarlama ile Karşılaştırılmalı Analizi: İzmir İli Urla İlçesi Balıklıva Köyü Örneği. XI. National Agricultural Congress. Samsun, 3-5 September, 1418-1427.

Akpınar, M. G., Özkan, B., Oral, M. A., \& Kızılay, H. (2009). Tüketicilerin Yaş Meyve Sebze Tedarik Kanalı Seçimi: Modern (Süper-Hipermarket) Perakendeciler. Akdeniz University, The Journal of Agricultural Faculty, 22(2), 211-221.

Albayrak, M. (2009). Yaş Meyve ve Sebze Pazarlama Merkezleri: Toptancı Haller-Pazarlar, Dünya, Avrupa Birliği ve Türkiye'den Örneklerle Yapısı ve İşleyişi. TKB TEAE Edition Number: 177.

Anonymous, (2018). Vegetable Farming Global Market Report 2018. The Business Research Company. Available:

https://www.thebusinessresearchcompany.com/report/vegetable-farming-global-market-report -2018 (01.08.2019)

Anonymous, (2019). Fruit and Nut Farming Global Market Report 2019. The Business Research Company. Available:

https://www.thebusinessresearchcompany.com/report/fruit-and-nut-farming-global-market-re port

Burt, L., Moulton, C., County, S., \& Kropf, J. (2008). Marketing Alternatives for Fresh Produce, Available:

http://extension.oregonstate.edu/catalog/pdf/pnw/pnw241-e.pdf(3.06.2016)

CBRT, (2016). Exchange Rates. Central Bank of the Republic of Turkey. Available: http://www.tcmb.gov.tr/wps/wcm/connect/TR/TCMB+TR/Main+Menu/Istatistikler/Doviz+K urlari/Gosterge+Niteligindeki+Merkez+Bankasi+Kurlarii/ (15.02.2016)

Çetin, B. (2009). Yeni Perakendecilik Sisteminde Toptancı Hallerinin İzlemesi Gereken Stratejiler, İstanbul Ticaret Odası Yayınları, Yayın No: 209-44, İstanbul.

Dastagiri, M. B., Ganesh Kumar, B., Hanumanthaiah, C. V., Paramsivam, P., Sidhu, R. S., 
Sudha, M., .. \& Chand, K. (2012). Marketing Efficiency of India's Horticultural Commodities under Different Supply Chains. Outlook on Agriculture, 41(4), 271-278. https://doi.org/10.5367/oa.2012.0103

Day, S. (2012). Rythu bazaars-A study of the benefits received by farmers. Asian Journal of Management Research, 3(1), 220-231.

FAO, (2016). Crops, Available: http://www.fao.org/faostat/en/\#data/QC (25.02.2016)

Henneberry, S. R., Whitacre, B., \& Agustini, H. N. (2009). An Evaluation of the Economic Impacts of Oklahoma Farmers Markets. Journal of Food Distribution Research, 40(3), 1-15.

Hussein, S. K., Venkatram, R., \& Ashok, K. R. (2013). Marketing Margin and Pricing Efficiency Analysis of Tomato Production in Sudan. Research, Journal of Economics and Business Studies, 2(12), 13-21.

Imtiyaz, H., \& Soni, P. (2013). Supply chain analysis of fresh guava (A case study). International Journal of Management and Business Research, 3(4), 373-382.

Kadanalı, E., \& Dağdemir, V. (2013). Yaş Meyve ve Sebze Pazarlamasında Aracılar Bakımından En Uygun Kanalın Belirlenmesi: Mersin İli Örneği. Anadolu Journal of Agricultural Sciences, 28(2), 77-81. https://doi.org/10.7161/anajas.2013.282.77

Kalaycı, Ş. (2014). SPSS Uygulamalı Çok Değişkenli İstatistik. Asil Yayın Dağıtım, Ankara.

Lucan, S. C., Maroko, A. R., Sanon, O., Frias, R., \& Schechter, C. B. (2015). Urban farmers' markets: Accessibility, offerings, and produce variety, quality, and price compared to nearby stores. Appetite, 90, 23-30. https://doi.org/10.1016/j.appet.2015.02.034

Martinez, S., Hand, M., Da Pra, M., Pollack, S., Ralston, K., Smith, T., ...\& Newman, C. (2010). Local Food Systems: Concepts, Impacts, and Issues. USDA, Economic Research Report, Number: 97, Washington, D.C., USA.

Miran, B. (2018). Genel İstatistik. Lambert Academic Publishing, Beau Bassin, Mauritus.

Mukherjee, D. N. (2013). Evaluation of the performance of Rythu Bazars in greater hyderabad-an economic analysis. Master Thesis of Science in Agriculture, Acharya N. G. Ranga Agricultural University, 120s.

Murthy, D. S., Gajanana, T. M., \& Dakshinamoorthy, V. (2007). Marketing Losses and Their Impact on Marketing Margins: A Case Study of Banana in Karnataka. Agricultural Economics Research Review, 20, 47-60.

Otto, D., \& Varner, T. (2005). Consumers, Vendors, and the Economic Importance of Iowa Farmers' Markets: An Economic Impact Survey Analysis, Iowa State University. Leopold Center for Sustainable Agriculture.

Pezikoğlu, F., Ergun, M. E., \& Erkal, S. (2004). Taze meyve-sebze pazarlama zincirinde modern perakendecilerin durumu. Bahçe dergisi, 33(1), 13-21.

Sanderson, K., Gertler, M., Martz, D., \& Mahabir, R. (2005). Farmers Markets in North America: A Background Document. Community-University Institute for Social Research, Saskatoon.

The Official Gazette, (2010). Law on Arrangement of the Trade of Vegetables and Fruits and Other Goods with Sufficient Supply and Demand Depth (Number: 27533), Available 
http://www.resmigazete.gov.tr/eskiler/2010/03/20100326-1.htm (8.02.2016)

TurkStat, (2018). The Production Amount of Vegetables and Fruit in Turkey. (01.08.2019) Available: https://biruni.tuik.gov.tr/medas/?kn=92\&locale $=\operatorname{tr}$

TZOB, (2003). Zirai ve İktisadi Rapor. (Agricultural and Economic Report) (2001-2002), Türkiye Ziraat Odaları Birliği, Edition Number: 244, Ankara.

Yurdakul, M. (2018). Türkiye Yaş Sebzelerin Dağitiminda Kullanilan Mevcut Dağitim Kanallari ve Gelecek Yönelimler Üzerine Bir Araştirma. Dumlupınar Üniversitesi Sosyal Bilimler Dergisi, (56), 128-140.

Yurdakul, O. (2002). Tarım Ürünleri Pazarlaması, Çukurova University Faculty of Agriculture Scoolbooks, Edition Number: A-39, Adana.

\section{Copyright Disclaimer}

Copyright for this article is retained by the author(s), with first publication rights granted to the journal.

This is an open-access article distributed under the terms and conditions of the Creative Commons Attribution license (http://creativecommons.org/licenses/by/4.0/). 